\title{
Environmental safety of entomopathogenic nematodes - Effects on abundance, diversity and community structure of non-target beetles in a forest ecosystem
}

\author{
Aoife B. Dillon ${ }^{\mathrm{a}, *}$, Aileen Foster ${ }^{\mathrm{b}}$, Christopher D. Williams ${ }^{\mathrm{b}}$, Christine T. Griffin ${ }^{\mathrm{b}}$

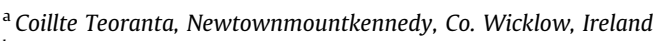 \\ ${ }^{\mathrm{b}}$ National University of Ireland, Maynooth, Co. Kildare, Ireland
}

\section{H I G H L I G H T S}

- EPN were applied to coniferous stumps to reduce populations of Hylobius abietis.

- Emergence of non-target beetles from control and EPN-treated stumps was examined.

$\checkmark 4$ trials were assessed in the year of nematode application and 10 in the subsequent year.

- 65 species of non-target beetles were recovered, including 11 saproxylic species.

- EPN had no effect on non-target beetle species richness, abundance or diversity.

\section{A R T I C L E I N F O}

Article history:

Received 21 October 2011

Accepted 8 July 2012

Available online 17 July 2012

\section{Keywords:}

Saproxylic Coleoptera

Tree stump fauna

Non-target effects

Biological control
G R A P H I C A L A B S T R A C T

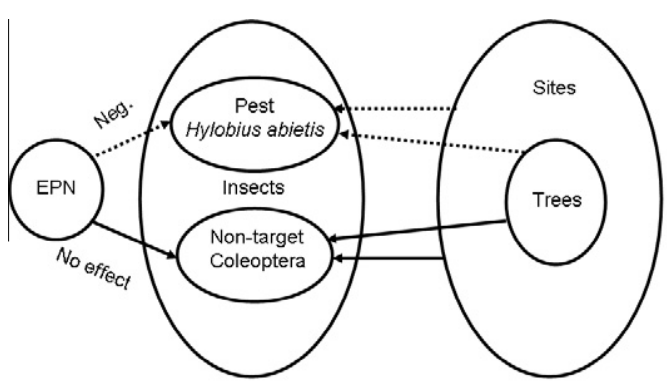

Arrows depict effects. Those labelled "neg" indicate a negative impact. EPN

$=$ Entomopathogenic nematodes. Soild arrows indicate the subject of this

study.

\begin{abstract}
A B S T R A C T
The large pine weevil, Hylobius abietis, is a serious threat to reforestation in Europe that necessitates routine use of chemical insecticides. Application of entomopathogenic nematodes (EPN) to the coniferous tree stumps in which weevils breed has the potential to reduce the use of chemical pesticides. During field trials to assess the efficacy of nematodes against pine weevil, non-target beetles were also identified and quantified on 10 sites (14 trials). Nematodes were applied to stumps between June and July. Emergence traps captured beetles exiting from nematode-treated and untreated control stumps. Four trials were monitored in the months immediately following nematode application and ten were monitored the year after nematode application.

A total of 65 species of non-target beetles were recovered, including 11 saproxylic species. We found no evidence of an effect of applied EPN on non-target beetle species richness, abundance, species richness per individual collected, or Shannon's entropy $\left(\mathrm{H}^{\prime}\right)$ either immediately or a year after nematode application, when more wood-specialists were recorded. As expected, there were marked differences between sites and/or tree species in the populations of non-target beetles recovered.

These results indicate that when EPN are applied in a forest ecosystem to suppress $H$. abietis populations, the risk to non-target coleopteran populations must be considered negligible.
\end{abstract}

(c) 2012 Elsevier Inc. All rights reserved.

\section{Introduction}

Although biological pest control is generally regarded as environmentally safer than the use of synthetic chemical insecticides,

\footnotetext{
* Corresponding author.

E-mail address: aoifebdillon@gmail.com (A.B. Dillon).
}

it is not risk free. Entomopathogenic nematodes (EPN) of the genera Steinernema and Heterorhabditis (Nematoda: Rhabditida) are widely used in inundative biological control programs. The pathogenicity of EPN is, in part, due to their associated symbiotic bacteria, Xenorhabdus and Photorhabdus (Steinernema spp. and Heterorhabditis spp., respectively) (Forst et al., 1997). The free living infective juvenile (IJ) stage actively seeks out insects in or on the 
soil, invading its host through natural openings. Following penetration, the nematode releases its symbiotic bacteria into the insect's hemocoel, causing insect death. After the cadaver is consumed, hundreds of thousands of IJs emerge into the soil and move off in search of fresh hosts.

In inundative programs, the rate of EPN application can be as high as $2.5-7.5 \times 10^{9} \mathrm{IJs}$ per hectare (Georgis et al., 2006). Nematode populations generally decline rapidly following application, though in some instances nematodes have been re-isolated a number of years after application (Dillon et al., 2008a; Koppenhofer and Fuzy, 2009; Millar and Barbercheck, 2001; Parkman et al., 1996).

Under laboratory conditions EPN have been shown to infect many insects from several orders, including Coleoptera, Diptera, Lepidoptera, Orthoptera, Siphonaptera and Thysanoptera (Georgis et al., 2006; Peters, 1996; Poinar, 1979; Puza and Mracek, 2010). With such a wide host range, it has been suggested that EPN could pose a risk to non-target insects, but the risk in the field may be reduced by limited dispersal and lack of persistence (van Lenteren et al., 2003; Lynch and Thomas, 2000). Avoidance of EPN infected insects or EPN occupied areas may further reduce adverse effects on non-target species under natural conditions (Ennis et al., 2010; Gouge, 2002). As such, detailed post application studies are the most realistic means of investigating potential non-target effects of EPN.

Buck and Bathon (1993) and Koch and Bathon (1993) looked at the effect of EPN (Steinernema feltiae Filipjev, Heterorhabditis megidis Poinar, Jackson, and Klein and Heterorhabditis bacteriophora Poinar) applied to a beech forest, the edge of a pine forest, an orchard and a wheat field. Approximately 400,000 insect specimens were collected in emergence traps. Koch and Bathon (1993) reported no significant impact on the population densities of arthropod groups of higher taxonomic ranks (Hymenoptera, Carabidae, Staphylinidae and other Coleoptera), or on most of the species recovered. Although the density of a few beetle species was significantly reduced, other species showed higher abundance on the test plots when compared with the untreated control, a result also observed by Buck and Bathon (1993). Georgis et al. (1991) collected non-target arthropods from turfgrass, corn, cabbage and cranberries following application of chemical insecticides or EPN (Steinernema carpocapsae Weiser, S. feltiae and H. bacteriophora). EPN had no effect on any of the non-target groups collected (Carabidae, Staphylinide, Gryllidae, Histeridae, Collembola, Gamasida, Actinedida or Oribatida). Wang et al. (2001) also found no evidence of any negative impact of EPN on non-target arthropods and nematodes in turf grass. On the contrary, Staphylinidae and Oribatida were significantly more abundant in EPN treated plots than in the untreated controls. Peck (2009) recorded a reduction in the abundance of hexapods (Insects and Collembola) in H. bacteriopho$r a$-treated turf plots in the year of application. This reduction was not observed when taxonomic groups were further divided. The lack of any significant deleterious impact on the abundance of non-target arthropods in the majority of previous studies, while encouraging, fails to take into account possible impacts on arthropod diversity, species richness or community structure.

The large pine weevil Hylobius abietis L. is a major obstacle to reforestation of coniferous plantations throughout northern Europe. Adult weevils are attracted to recently cut coniferous sites by the volatiles emitted during felling. Females lay their eggs in the stumps, where development takes 2-4 years (Leather et al., 1999; Norlander et al., 1997). Emerging adult weevils feed on young seedlings, often causing plant death. Following on from successful small-scale trials (Brixey, 2000; Dillon et al., 2006, 2007), EPN have been used in UK and Irish forestry since 2004 and 2007, respectively. EPN are applied 12-18 months after felling, when $H$. abietis are late instar larvae and pupae. At this time the diversity of Coleoptera in the stumps is generally low, though over time this increases (Wallace, 1953). Our hypothesis is that non-target Coleoptera species richness, Shannon's entropy ${ }^{1}$ and community composition will not be adversely affected in the year of nematode application (when species richness and diversity are low). As EPN populations around stumps can remain high for 34 years after application (Dillon et al., 2008a), we hypothesize that adverse non-target effects may be observed once stumps are colonized by other coleopterans. This study is the first to examine whether EPN impact on non-target Coleoptera species richness, abundance, Shannon's entropy or community structure in a forest ecosystem.

\section{Methods}

\subsection{Nematodes}

Two nematode species were tested, commercially produced $S$. carpocapsae All strain and laboratory produced Heterorhabditis downesi Stock, Burnell and Griffin, K122 strain. Commercially produced $S$. carpocapsae was supplied on an inert carrier in a powder formulation (Beckerunderwood, UK) and stored at $4{ }^{\circ} \mathrm{C}$ for up to 3 weeks prior to application. On the day of application the product was mixed with water on site in the mixing tank, to a concentration of approximately $6 \times 10^{6} \mathrm{IJs} / \mathrm{L}$. H. downesi was produced in vivo in Galleria mellonella L. (Woodring and Kaya, 1988). Harvested IJs were washed by sedimentation in three changes of tap water and stored for up to a week at $9{ }^{\circ} \mathrm{C}$ at a concentration of approximately 5,000 IJs/L. On the day of application $H$. downesi concentrations were adjusted to $7 \times 10^{6} \mathrm{IJs} / \mathrm{L}$ in $5 \mathrm{~L}$ bottles. Bottles were shaken regularly to ensure $H$. downesi IJs remained in suspension. Nematode-treated stumps received approximately $500 \mathrm{ml}$ of nematode suspension, applied either using a spray gun attached to the forwarder-mounted mixing tank (S. carpocapsae), or by hand (H. downesi). The rate applied per stump was therefore 3$3.5 \times 10^{6}$ IJs.

\subsection{Trials}

2007 trials (Monitored in year after EPN application):

Six sites (see Table 1 for details) were monitored for non-target effects. On five sites, $S$. carpocapsae was applied by pressure hose from a forwarder-mounted mixer tank to the majority of stumps. On the sixth site (Knockeen), excessive vegetation prevented the safe use of the forwarder so $S$. carpocapsae was applied by hand. On three of the sites, trials were run on two or more tree species, giving a total of ten trials. Tree species tested were Sitka spruce (Picea sitchensis Bong. Carr), Lodgepole pine (Pinus contorta Douglas), Japanese larch (Larix kaempferi Lamb. Carr) and Noble Fir (Abies procera Rehder). Six trials compared S. carpocapsae, H. downesi and untreated controls, while the remaining four trials compared only S. carpocapsae and untreated controls. Between 15 and 21 stumps per tree species per site were set aside as untreated controls, with a comparable number of stumps treated with $H$. downesi. All other accessible stumps within the site were treated with $S$. carpocapsae. Within each trial, experiments were set out in a randomized block design with one stump of each treatment per block. Some stumps were damaged during forestry operations and lost from the trials. Within each trial, numbers of stumps were approximately equal for each treatment. Nematodes were applied to the soil only around the circumference of the treated stumps, as pine weevils are located directly under the bark of the stump.

\footnotetext{
1 A recent review by Jost (2007), which has been widely accepted, has resulted in what was previously described as Shannon's diversity now being termed Shannon's entropy (stilled designated H'). Shannon's diversity is now properly used to describe $\mathrm{e}^{\mathrm{H}^{\prime}}$.
} 
Table 1

Site details and numbers of tree stumps.

\begin{tabular}{|c|c|c|c|c|c|c|c|}
\hline \multirow[t]{2}{*}{ Site } & \multirow[t]{2}{*}{ Soil type ${ }^{a}$} & \multirow[t]{2}{*}{ Coordinates } & \multirow[t]{2}{*}{ Felling date } & \multirow[t]{2}{*}{ Tree species } & \multicolumn{3}{|c|}{ Treatment No. of stumps } \\
\hline & & & & & Con & Sc & Hd \\
\hline \multicolumn{8}{|l|}{2007 Trials } \\
\hline \multirow{3}{*}{$\begin{array}{l}\text { Deerpark, } \\
\text { Co. Wicklow }\end{array}$} & Peaty & $53^{\circ} 08^{\prime} \mathrm{N}$ & $02 / 2006$ & Spruce & 21 & 21 & 21 \\
\hline & Podsol & $06^{\circ} 12^{\prime} \mathrm{W}$ & & & & & \\
\hline & & & & Larch & 18 & 18 & $\mathrm{~N} / \mathrm{A}$ \\
\hline \multirow{2}{*}{$\begin{array}{l}\text { Knockeen, } \\
\text { Co. Waterford }\end{array}$} & Peat & $52^{\circ} 12^{\prime} \mathrm{N}$ & $04 / 2006$ & Spruce & 15 & 15 & 15 \\
\hline & & $07^{\circ} 10^{\prime} \mathrm{W}$ & & & & & \\
\hline \multirow{3}{*}{$\begin{array}{l}\text { Lackenrea, } \\
\text { Co. Waterford }\end{array}$} & Peaty & $52^{\circ} 09^{\prime} \mathrm{N}$ & $02 / 2006$ & Spruce & 13 & 14 & 15 \\
\hline & Podsol & $07^{\circ} 48^{\prime} \mathrm{W}$ & & & & & \\
\hline & & & & Pine & 14 & 16 & 16 \\
\hline \multirow{2}{*}{$\begin{array}{l}\text { Ballymacshaneboy, } \\
\text { Co. Cork }\end{array}$} & Peat & $52^{\circ} 18^{\prime} \mathrm{N}$ & $06 / 2006$ & Pine & 13 & 14 & 13 \\
\hline & & $08^{\circ} 35^{\prime} \mathrm{W}$ & & & & & \\
\hline \multirow{2}{*}{$\begin{array}{l}\text { Glendine, } \\
\text { Co. Laois }\end{array}$} & Peat & $53^{\circ} 05^{\prime} \mathrm{N}$ & $12 / 2006$ & Pine & 19 & 19 & 19 \\
\hline & & $07^{\circ} 34^{\prime} \mathrm{W}$ & & & & & \\
\hline \multirow{4}{*}{$\begin{array}{l}\text { The Rodneys, } \\
\text { Co. Limerick }\end{array}$} & Mineral & $52^{\circ} 15^{\prime} \mathrm{N}$ & $02 / 2006$ & Spruce & 18 & 18 & $\mathrm{~N} / \mathrm{A}$ \\
\hline & & $08^{\circ} 56^{\prime} \mathrm{W}$ & & & & & \\
\hline & & & & Larch & 15 & 15 & $\mathrm{~N} / \mathrm{A}$ \\
\hline & & & & Fir & 20 & 20 & $\mathrm{~N} / \mathrm{A}$ \\
\hline \multicolumn{8}{|l|}{2008 Trials } \\
\hline \multirow{2}{*}{$\begin{array}{l}\text { Mount Leinster, } \\
\text { Co. Carlow }\end{array}$} & Mineral & $53^{\circ} 37^{\prime} \mathrm{N}$ & $06 / 2007$ & Spruce & 20 & 20 & $\mathrm{~N} / \mathrm{A}$ \\
\hline & & $06^{\circ} 47^{\prime} \mathrm{W}$ & & & & & \\
\hline \multirow{2}{*}{$\begin{array}{l}\text { Drumcor, } \\
\text { Co. Cavan }\end{array}$} & Mineral & $54^{\circ} 06^{\prime} \mathrm{N}$ & $04 / 2007$ & Spruce & 10 & 10 & $\mathrm{~N} / \mathrm{A}$ \\
\hline & & $07^{\circ} 16^{\prime} \mathrm{W}$ & & & & & \\
\hline \multirow{2}{*}{$\begin{array}{l}\text { Featherbed, } \\
\text { Co. Wicklow }\end{array}$} & Mineral & $53^{\circ} 14^{\prime} \mathrm{N}$ & $01 / 2007$ & Spruce & 13 & 13 & $\mathrm{~N} / \mathrm{A}$ \\
\hline & & $06^{\circ} 20^{\prime} \mathrm{W}$ & & & & & \\
\hline \multirow{2}{*}{$\begin{array}{l}\text { Glenakeel, } \\
\text { Co. Cork }\end{array}$} & Peat & $52^{\circ} 15^{\prime} \mathrm{N}$ & $06 / 2007$ & Spruce & 20 & 20 & $\mathrm{~N} / \mathrm{A}$ \\
\hline & & $09^{\circ} 12^{\prime} \mathrm{W}$ & & & & & \\
\hline
\end{tabular}

Con = untreated control; $\mathrm{Sc}=$ Steinernema carpocapsae; $\mathrm{Hd}=$ Heterorhabditis downesi .

a Soil type was based on information in Coillte's Forest Inventory System.

Nematodes were applied in July 2007; non-target beetles were collected from March/April to October 2008 (detecting beetles present in the year after nematode application).

2008 trials (Monitored in year of EPN application):

Four sites (see Table 1 for details) were monitored for non-target effects. On each site trials were run on a single tree species only (Sitka spruce), using only a single nematode species (S. carpocapsae). Between 10 and 20 stumps per site were set aside as untreated controls. In each trial experiments were set out in a randomized block design with one stump of each treatment per block. Nematodes were applied from a forwarder-mounted mixing tank, as in 2007 trials. Nematodes were applied in June 2008 and non-target beetles were collected from July to October 2008 (detecting beetles present in the year of nematode application).

\subsection{Collection and identification of Coleoptera}

Stumps were covered with insect emergence traps designed to catch emerging $H$. abietis adults as described by Dillon et al. (2006). Traps were emptied monthly and Coleoptera were determined to species using Forsythe (2000), Joy (1932), Lindroth (1974) and Luff (2007). Identifications of some species were confirmed by Dr. Roy Anderson (AFBI, Northern Ireland) and by the British Museum (Natural History), UK. Species were classified as wood-associated/saproxylic based on The Saproxylic Database (Anon, 2011) and Alexander (2002).

\subsection{Statistical analysis}

Four parameters are reported for each treatment (nematodes or control) for each trial: species richness (the number of beetle species recorded); abundance of Coleoptera (total number of individual beetles collected), species richness per individual collected and Shannon's entropy. Routine statistics were performed using MINITAB Release 15 for Windows (MINITAB Inc, 2007). Data were tested for normality using the Anderson-Darling test and, where found to be non-normal, data were log transformed prior to analysis. Analysis of variance (ANOVA) was used to test whether treatment affected any of these parameters using trials (site or site/tree species) as replicates. In the year of nematode application, $\mathrm{H}$. abietis captures in emergence traps on all sites were compared to control stumps in order to verify that EPN did in fact reduce $H$. abietis numbers.

Community analysis: we performed multi-response permutation procedure (MRPP) on a Euclidean (Pythagorean) dissimilarity matrix for both the whole coleopteran fauna and the sub-set of saproxylic beetles for the field trials that were sampled one year post-application (2007 trials).

To compare similarity patterns of the Coleoptera composition, we performed Non-metric multi-dimensional scaling (NMS) on the full coleopteran community data that were collected one year post-application (2007) trials. NMS is an ordination technique based on minimizing stress between the ordination and the multi-dimensional dissimilarity matrix (Kenkel and Orlóci, 1986). Data were relativized by site prior to analysis and different overlays were used to aid visualization of clustering.

We performed indicator species analysis (Dufrene and Legendre, 1997) on both the complete coleopteran data-set and the sub-set of saproxylic beetles from the one year post-application (2007) trials. All multivariate statistics were performed using PCOrd Version 5 (McCune and Grace, 2002).

\section{Results}

\subsection{Diversity and abundance of beetles collected in emergence traps}

Sixty-five species of beetle, other than $H$. abietis, were recovered and identified. Beetles collected in emergence traps represented various guilds including predators, herbivores, detritivores, dungfeeders, carrion-feeders and wood boring beetles (Table 2). Across 
Table 2

Number of non-target beetle families, species and individuals captured during the 2008 sampling, following the application of EPN to stumps containing $H$. abietis.

\begin{tabular}{|c|c|c|c|c|c|c|}
\hline \multirow[t]{2}{*}{ Family } & \multirow[t]{2}{*}{ Functional Group } & \multirow[t]{2}{*}{ Habitat } & \multicolumn{2}{|l|}{2007 Trials } & \multicolumn{2}{|l|}{2008 Trials } \\
\hline & & & No. species & No. individuals & No. species & No. individuals \\
\hline Apionidae & Herbivore & NW & 1 & 1 & & \\
\hline Byrrhidae & Herbivore & NW & 2 & 61 & 1 & 1 \\
\hline Cantharidae & Predator & NW & 1 & 2 & & \\
\hline Carabidae & Predator & NW & 18 & 398 & 13 & 147 \\
\hline Cerambycidae & Wood borers & W & 2 & 1132 & & \\
\hline Chrysomelidae & Herbivore & NW & 4 & 7 & & \\
\hline Coccinellidae & Predator & NW & 2 & 30 & & \\
\hline Curculionidae & Herbivore & NW & 8 & 178 & 4 & 17 \\
\hline Elateridae & Wood borers & $\mathrm{W}$ & 4 & 88 & & \\
\hline Elateridae & Herbivore & NW & 3 & 346 & & \\
\hline Geotrupidae & Detritivore & NW & & & 2 & 17 \\
\hline Helophoridae & Herbivore & NW & & & 1 & 1 \\
\hline Histeridae & Dung feeder & NW & 1 & 4 & & \\
\hline Hydrophilidae & Predator & NW & 1 & 46 & & \\
\hline Lymexylidae & Wood borers & W & 1 & 17 & & \\
\hline Nitidulidae & Herbivore & $\mathrm{W}$ & 1 & 8 & & \\
\hline Scarabaeidae & Dung feeder & NW & 1 & 1 & & \\
\hline Scolytidae & Wood borers & $\mathrm{W}$ & 2 & 154 & 2 & 7 \\
\hline Silphidae & Carrion feeder & NW & 6 & 40 & 3 & 14 \\
\hline Staphylinidae & Predator & NW & 3 & 102 & 3 & 8 \\
\hline Tenebrionidae & Herbivore & $\mathrm{W}$ & 1 & 419 & 1 & 1 \\
\hline Total number & & & 62 & 3034 & 30 & 213 \\
\hline No. of stumps & & & 435 & & 126 & \\
\hline
\end{tabular}

$\mathrm{NW}=$ species not typically found associated with wood, $\mathrm{W}$ = species typically found associated with wood.

all trials 3247 individual beetles were collected. Beetle abundance was four times higher in the 2007 trials than in the 2008 trials (averaging 7.0 and 1.7 beetles per stump, respectively). Eleven species were classified as saproxylic (wood-associated) as they develop and/or feed in wood. Numbers and Shannon's entropy of saproxylic beetles were higher in the 2007 trial: 1,818 individuals were recovered from 11 species, of which the most abundant was the pine longhorn beetle Asemum striatum L. Only three saproxylic species (Hylastes ater Payk, Scolytus scolytus F. and Cylindronotus laevioctostriatus Goeze), numbering eight individuals in total, were recovered in the 2008 trials i.e. the year of EPN application where stumps were one year younger when the insects were collected.

\subsection{Do nematodes affect numbers or diversity of non-target beetles?}

There was evidence of a population reduction of $H$. abietis by EPN on all but three sites (Knockeen, Featherbed and Glenakeel), where emergence traps revealed weevil populations of less than 1 weevil per control stump. Nematode efficacy, when measured as the reduction in emergence of $H$. abietis relative to control stumps in the year of application, varied across sites and nematode species: $7-90 \%$ for $S$. carpocapsae and $63-80 \%$ for $H$. downesi.

Data on species richness, abundance of Coleoptera per stump, species richness per individual collected and the corresponding Shannon's entropy for each treatment in each trial is given in Table 3. Analysis of those data (Table 4) shows that nematode treatment had no effect on any of the parameters measured in either years' trials. The parameter "site/tree species" did, however, have a significant effect on all these variables in the one year post-application trials (2007). "Site" had a significant effect on the species richness per individual collected in the year of application trials (2008) (Table 4).

The 2007 trials data is the more extensive data-set and was thus more likely to reveal a reduction in numbers due to nematodes than the 2008 trials data. These data were subject to further analysis, taking into account the entire beetle community and also the subset that are identified as saproxylic. Location (site) is an important factor in determining the beetle community composition when we consider both the total community (approximately 25\% of the variation in beetle composition can be accounted for by differences in location) and the sub-set of saproxylic beetles (approximately 24\% of variation accounted for) (MRPP, $P<0.001$ and $P<0.01$, respectively). Tree species is important in the whole beetle community data-set (MRPP, $P<0.05$ ), and the effect of tree species approached significance (MRPP, $P=0.06$ ) for the saproxylic sub-set. In neither case was "treatment" (i.e. S. carpocapsae-treated versus $H$. downesi-treated versus untreated controls) a significant grouping variable, indicating no observable influence of nematode treatment on the stump Coleoptera fauna for the one year-post application (2007) field trials.

For the data-set of all Coleoptera collected from one year postapplication (2007), the NMS ordination of sites in species-space resulted in a 3-dimensional ordination with a final stress of 11.15 and a final instability of 0.00226 after 500 iterations. The proportion of variance explained by each axis, measured as the coefficients of determination for the correlations between ordination distances and distances in the original 66-dimensional space, were 0.330 , 0.208 and 0.339 for axes 1,2 and 3, respectively. The orthogonality of axes 1 versus 3 was $99.8 \%$. A plot of axes 1 versus 3 , for the whole coleopteran fauna, is shown in Fig. 1. The clustering of locations (Fig. 1a) was largely as a result of tree species clustering (Fig. 1b). There was no observable clustering of treatments (Fig. 1c). These results support the conclusions of the MRPP that nematode treatment does not significantly affect coleopteran community composition. Furthermore, a cluster analysis using flexible beta linkage (beta $=-0.25$ ) and Euclidean distance on data relativized by sites, supports the conclusions of the ordinations and the MRPP i.e. a clustering of data points by location and tree species, but not by nematode treatment (cluster analyses are not presented here).

Indicator species analysis of the whole coleopteran fauna (65 species) did not reveal any significant indicators of the treatment variable (control versus $S$. carpocapsae versus $H$. downesi) or when the grouping variable was selected as control versus nematode treatment (analysis not shown). In contrast to this finding, when the saproxylic fauna was subjected to indicator species analysis, Hylastes ater was a significant indicator of $H$. downesi treatment with an indicator value of $60.3 \%$ of perfect indication and a significance of $P=0.0084$. When the grouping variable was changed to control versus nematode treatment, there were no significant indicators. 
Table 3

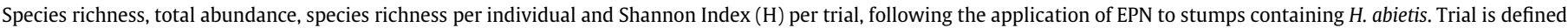
as tree species per site.

\begin{tabular}{|c|c|c|c|c|c|c|c|}
\hline Site & $\begin{array}{l}\text { Tree } \\
\text { species }\end{array}$ & Treatment & $\begin{array}{l}\text { \% Reduction in No. of emerging } H \text {. } \\
\text { abietis }^{\mathrm{a}}\end{array}$ & $\begin{array}{l}\text { Species } \\
\text { richness }\end{array}$ & $\begin{array}{l}\text { Total } \\
\text { abundance }\end{array}$ & $\begin{array}{l}\text { Species richness per } \\
\text { individual }\end{array}$ & $\begin{array}{l}\text { Shannon Index } \\
(H)\end{array}$ \\
\hline \multicolumn{8}{|l|}{2007 Trials } \\
\hline \multirow[t]{5}{*}{ Deerpark } & \multirow[t]{3}{*}{ Spruce } & Con & & 18 & 81 & 0.22 & 2.599 \\
\hline & & Sc & 32 & 16 & 138 & 0.16 & 2.089 \\
\hline & & Hd & 74 & 19 & 114 & 0.17 & 2.361 \\
\hline & \multirow[t]{2}{*}{ Larch } & Con & & 24 & 338 & 0.07 & 2.075 \\
\hline & & Sc & 7 & 23 & 379 & 0.06 & 1.658 \\
\hline \multirow[t]{3}{*}{ Knockeen } & \multirow[t]{3}{*}{ Spruce } & Con & & 12 & 82 & 0.15 & 1.455 \\
\hline & & Sc & 40 & 13 & 65 & 0.20 & 2.222 \\
\hline & & Hd & 80 & 17 & 76 & 0.22 & 2.238 \\
\hline \multirow[t]{6}{*}{ Lackenrea } & \multirow[t]{3}{*}{ Spruce } & Con & & 14 & 108 & 0.13 & 1.764 \\
\hline & & Sc & 42 & 21 & 167 & 0.13 & 1.475 \\
\hline & & Hd & 79 & 15 & 157 & 0.10 & 1.331 \\
\hline & \multirow[t]{3}{*}{ Pine } & Con & & 13 & 82 & 0.16 & 2.144 \\
\hline & & Sc & 29 & 13 & 286 & 0.05 & 0.701 \\
\hline & & Hd & 63 & 16 & 70 & 0.23 & 1.937 \\
\hline \multirow[t]{3}{*}{ Ballymacshaneboy } & \multirow[t]{3}{*}{ Pine } & Con & & 9 & 19 & 0.47 & 1.908 \\
\hline & & Sc & 11 & 7 & 27 & 0.26 & 1.704 \\
\hline & & Hd & 74 & 5 & 18 & 0.28 & 1.388 \\
\hline \multirow[t]{3}{*}{ Glendine } & \multirow[t]{3}{*}{ Pine } & Con & & 9 & 50 & 0.18 & 1.878 \\
\hline & & Sc & 72 & 8 & 25 & 0.32 & 1.778 \\
\hline & & Hd & 81 & 8 & 32 & 0.25 & 1.619 \\
\hline \multirow[t]{6}{*}{ The Rodneys } & \multirow[t]{2}{*}{ Spruce } & Con & & 17 & 97 & 0.18 & 2.366 \\
\hline & & Sc & 33 & 12 & 97 & 0.12 & 1.859 \\
\hline & \multirow[t]{2}{*}{ Larch } & Con & & 23 & 111 & 0.21 & 2.725 \\
\hline & & Sc & 67 & 24 & 168 & 0.14 & 2.475 \\
\hline & \multirow[t]{2}{*}{ Fir } & Con & & 27 & 134 & 0.20 & 2.746 \\
\hline & & Sc & $\mathrm{N} / \mathrm{A}^{\mathrm{b}}$ & 24 & 113 & 0.21 & 2.534 \\
\hline \multicolumn{8}{|l|}{2008 Trials } \\
\hline \multirow[t]{2}{*}{ Mount Leinster } & \multirow[t]{2}{*}{ Spruce } & Con & & 13 & 26 & 0.50 & 2.418 \\
\hline & & Sc & 90 & 2 & 3 & 0.66 & 0.637 \\
\hline \multirow[t]{2}{*}{ Drumcor } & \multirow[t]{2}{*}{ Spruce } & Con & & 15 & 33 & 0.45 & 2.515 \\
\hline & & $\mathrm{Sc}$ & 63 & 9 & 21 & 0.43 & 1.996 \\
\hline \multirow[t]{2}{*}{ Featherbed } & \multirow[t]{2}{*}{ Spruce } & Con & & 7 & 44 & 0.16 & 1.530 \\
\hline & & $\mathrm{Sc}$ & $\mathrm{N} / \mathrm{A}^{\mathrm{b}}$ & 5 & 22 & 0.23 & 1.116 \\
\hline \multirow[t]{2}{*}{ Glenakeel } & \multirow[t]{2}{*}{ Spruce } & Con & & 13 & 29 & 0.45 & 2.239 \\
\hline & & Sc & $\mathrm{N} / \mathrm{A}^{\mathrm{b}}$ & 14 & 35 & 0.40 & 2.409 \\
\hline
\end{tabular}

Con = untreated control; $\mathrm{Sc}=\mathrm{S}$. carpocapsae; $\mathrm{Hd}=\mathrm{H}$. downesi .

a \% Reduction relative to control in numbers of weevils emerging in year of nematode application.

b Mean of less than 1 Hylobius recovered per control stump, so \% reduction not calculated.

Table 4

Effect of site/tree species and nematode treatment on the abundance and diversity of non-target Coleoptera collected in emergence traps for field trials in 2007 and 2008.

\begin{tabular}{|c|c|c|c|c|c|c|}
\hline \multirow[t]{2}{*}{ Parameter } & \multicolumn{3}{|c|}{ Site/tree species ${ }^{\mathrm{a}}$} & \multicolumn{3}{|c|}{ Nematode treatment ${ }^{\mathrm{b}}$} \\
\hline & df & $F$ & $P$ & df & $F$ & $P$ \\
\hline \multicolumn{7}{|l|}{1 Year post-treatment (2007 trials) } \\
\hline Species richness & 9 & 19.11 & $<0.001$ & 2 & 0.555 & 0.582 \\
\hline Abundance of Coleoptera/stump ${ }^{c}$ & 9 & 7.898 & $<0.001$ & 2 & 1.090 & 0.353 \\
\hline Species richness/individual collected & 9 & 3.492 & 0.014 & 2 & 0.612 & 0.551 \\
\hline Shannon Index H & 9 & 2.906 & 0.030 & 2 & 1.451 & 0.255 \\
\hline \multicolumn{7}{|l|}{ Year of application (2008 trials) } \\
\hline Species richness & 3 & 1.259 & 0.400 & 1 & 2.077 & 0.200 \\
\hline Abundance of Coleoptera /stump ${ }^{c}$ & 3 & 2.349 & 0.214 & 1 & 1.710 & 0.239 \\
\hline Species richness/individual collected & 3 & 11.778 & 0.019 & 1 & 0.113 & 0.748 \\
\hline Shannon Index H & 3 & 1.129 & 0.437 & 1 & 1.901 & 0.217 \\
\hline
\end{tabular}

a Site/tree species: each tree species on each site treated separately.

b Nematode treatments: control, S. carpocapsae or H. downesi for 2007 and control or S. carpocapsae for 2008.

c Number of individuals of all species, divided by number of stumps (blocks).

\subsection{Do nematodes affect abundance of the pine longhorn beetle A. striatum?}

A. striatum was numerically the dominant beetle in the 2007 trials. This species accounted for one-third of all beetles collected and
$57 \%$ of saproxylic beetles, and was present at five of the six 2007 sites. In most site/tree species, stumps treated with $S$. carpocapsae yielded more $A$. striatum than the untreated controls (data not shown). Analysis of the total number of insects per treatment showed that the effect of site/tree species was highly significant 

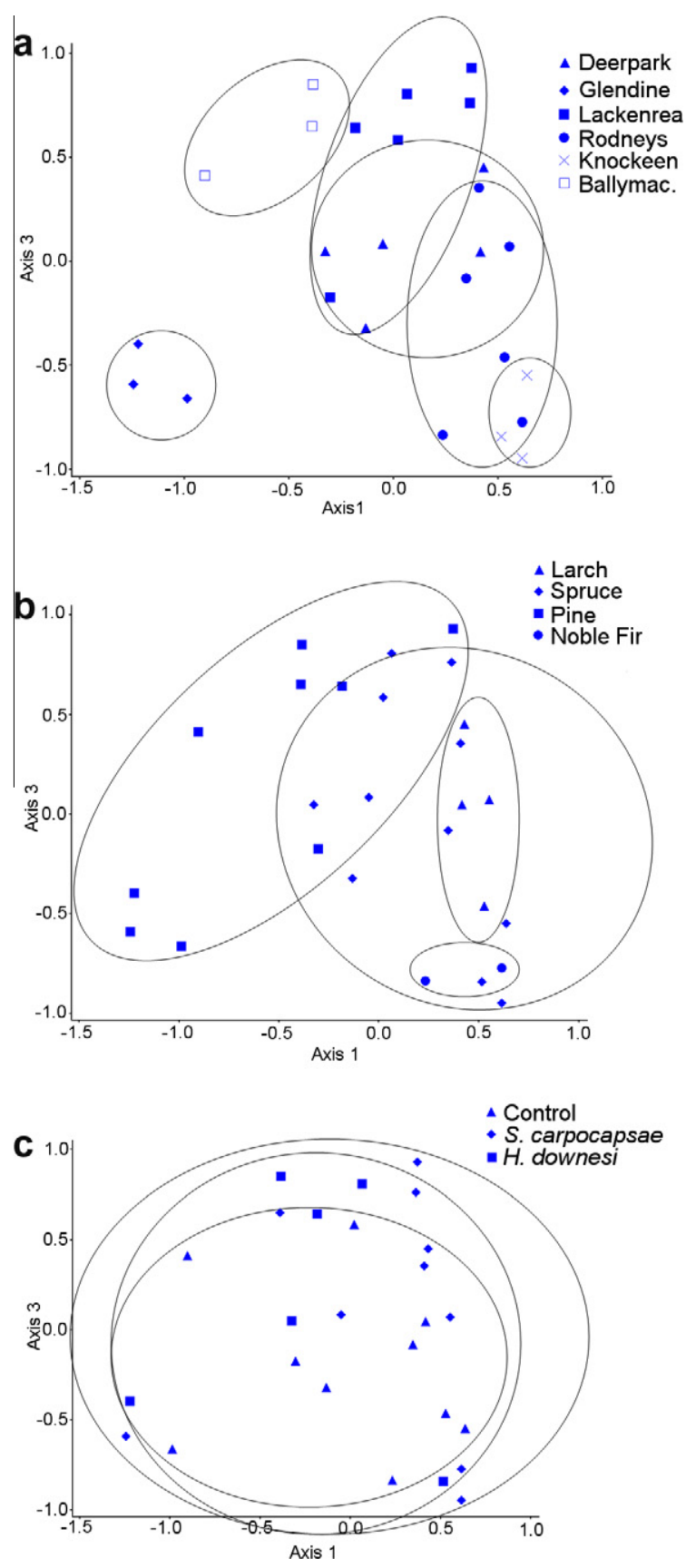

Fig. 1. Non-metric multidimensional scaling ordination of sites (overlaid by location (a), tree species (b) and treatment (c)) in species-space for the one year post-treatment (2007 trials) data-set. The ordination is for the full coleopteran community. Axis 1 represents $33.0 \%$ and axis 3 represents $33.9 \%$ of the variance in the species dissimilarity matrix. Ovals and circles encompass the overlay points demonstrating clustering with respect to (a) and (b), but not (c).

( $F=16.152, \mathrm{df}=9,14 P<0.001)$. The effect of nematodes approached significance $(F=3.26, \mathrm{df}=2,14 P=0.069)$, with more $A$. striatum in stumps treated with $S$. carpocapase (average 67 insects per site/tree) compared to untreated or $H$. downesi-treated stumps (20 and 36 insects, respectively).

A. striatum has a highly aggregated distribution: most stumps had none, a few yielded more than 50 and one $S$. carpocapsae-treated stump had 218 (data not shown). Analysis was therefore repeated using the data for each individual stump. This showed that nematodes (treatment) did not have an effect on $A$. striatum $(F=1.68, \mathrm{df}=2,409 P>0.05)$, but confirmed that the effect of site/tree species was highly significant $(F=16.152, \mathrm{df}=9,409$ $P<0.001)$.

\section{Discussion}

Of the genera recovered in these trials, many are reportedly susceptible to EPN under laboratory and/or field conditions, including: Coccinella (Shapiro-Ilan and Cottrell, 2005), Adalia (Rojht et al., 2009), Altica (Tomalak, 2004), Phyllotreta (Trdan et al., 2008), Otiorhynchus (Lola-Luz and Downes, 2007), Hylastes (Dillon et al., 2008b) and Sitona (Loya and Hower, 2003). It is possible that some individuals from these genera were killed by the applied EPN, but when quantifying risk it is the population, not the individual that is important. In general, the majority of nematodes remain close to the point at which they were applied (e.g. Csontos, 2002; Dillon et al., 2008a), therefore monitoring non-targets at the stumps, rather than more generally on sites was considered appropriate. Despite extensive monitoring of this 'risky' area, we found no evidence of any effect on non-target beetle species richness, abundance, species richness per individual collected, or Shannon's entropy ( $\left.\mathrm{H}^{\prime}\right)$ either in the months immediately following application (2008 trials) or a year after nematode application, when more saproxylics were recorded (2007 trials).

Changes in species abundance have been observed following application of EPN to the soil, though rather than arthropod abundance being adversely affected, a number of authors have reported the opposite. Wang et al. (2001) reported an increase in the occurrence of staphilinid beetles and oribatid mites, while Jabbour and Barbercheck (2011) found that arthropod communities responded positively to the addition of added resources (insect cadavers). In the latter case, the authors hypothesized that responding arthropods were likely to be opportunistic scavengers feeding on the insect cadaver or on the nematophagous groups such as mites or Collembola. These results would suggest that rather than avoiding 'risky' nematode-infected areas, certain arthropods are actually attracted into these areas, or are more successful at exploiting the resource in these areas. In our trials, on initial examination, both EPN species were associated with higher populations of a single insect species: H. downesi with the bark beetle Hylastes ater and S. carpocapsae with the longhorn beetle A. striatum. Both beetle species had a highly aggregated distribution. The apparent effect of $S$. carpocapsae on A. striatum was not evident when the analysis was conducted on data for individual stumps. Hylastes ater numbers were too low to carry out analysis on a per stump basis.

The beetles recovered in this study consist of both casual intruders and true stump-fauna. As casual intruders are likely to occupy the 'risky' nematode-occupied space for only a short time, the risk to these species must be considered lower than to the true stump fauna. Analysis of only the entire pooled data-set could potentially obscure effects on the more high risk non-target species. Insects that spend most of their lives in wood (e.g. longhorn beetles) are more likely to be impacted by nematodes, given the fact that the insects and nematodes will occupy the same space for a longer period of time. Although the longhorn beetle A. striatum was present at reasonable numbers in the 2007 trials, there was no evidence that nematodes had any negative impact on populations of this species. A second longhorn beetle, Rhagium bifasciatum was also recorded from the 2007 trial. $R$. bifasciatum is susceptible to EPN, and although parasitized individuals have been recovered on sites where EPN have been applied (Harvey et al., 2012), the lack of any significant effect in these trials reiterates the general theme that effects on the individual do not necessarily translate into effects on the population.

A number of studies have shown that the species composition of saproxylic beetles is heavily influenced by tree species (e.g. 
Jonsell et al., 2007; Lindhe and Lindelöw, 2004). In our study, there were marked differences between sites and/or tree species in the populations of non-target beetles recovered. In the months immediately following nematode application (2008 trials) species richness per individual collected was the only parameter where differences were significant, though for 1 year post treatment (2007 trials) there was a significant effect of site/tree species on all parameters measured (species richness, abundance, species richness per individual collected and Shannon's entropy). In our trials EPN were applied to stumps of four different tree species (spruce, pine, larch and fir) (2007 trials). As all species were not available on all sites, it was not possible, using ANOVA, to differentiate statistically between differences due to sites and those due tree species. Analysis of the community assemblages (as evident in the MRPP analysis and NMS ordination of sites), revealed that both tree species and location influenced community assemblages of the total beetle fauna. The community assemblage of saproxylic beetles was influenced by location, but not tree species. It is not unexpected that intrinsic site factors determine a carabid-rich coleopteran community structure (e.g. Tyler, 2008), but it is somewhat surprising that the effect of tree species was less apparent when only saproxylic species were analyzed $(P=0.06)$ than when all species were included $(P=0.034)$.

The greater diversity observed in the 2007 trials compared to the 2008 trials is most likely due to the time elapsed since felling: in the 2007 trials trees had been felled 19-33 months previously, while in the 2008 trials, trees had been felled 1321 months previously. We would expect wood properties in stumps of different species to change at different rates post felling, thus creating more diverse microhabitats and niches, so it is not surprising that the effect of site/tree species was more pronounced on older sites. In a Swedish study, Jonsell et al. (2007) looked at the species of saproxylic beetle in 1 year old and 35 year old logging residues and found that for all tree species tested (aspen, birch, oak and spruce), species richness was higher on older sites.

\section{Conclusion}

When quantifying the environmental risk of applying EPN, based only on their broad physiological host range, a simplistic conclusion could be that nematodes poses a risk to non-target insects. Delfosse (2005) argued that risk is a relative concept used to imply uncertainty, and estimates and perceptions of risk change as knowledge improves. Therefore, based on the results of this study, when EPN are applied in a forest ecosystem to control H. abietis populations, the risk to non-target coleopteran populations must be considered negligible.

\section{Acknowledgments}

This work was funded by the Irish National Development Plan through COFORD, the National Council for Forest Research and Development (ABATE project). CDW was part funded by the European Regional Development Fund (ERDF) through the Ireland Wales Programme (INTERREG 4A). Nematodes were applied under license from the Irish National Parks and Wildlife Service and the Pesticide Control Service division of the Department of Agriculture, Fisheries and Food. The authors wish to thank Dr Roy Anderson, formerly of AFBI, Northern Ireland, for identifying a number of insect specimens and Dr Christopher Harvey (NUIM) for improving the quality of the manuscript figures. We are also grateful to Coillte personnel who emptied the insect emergence traps.

\section{References}

Anon, 2011. The Saproxylic Database: Biodiversity in deadwood. <http:// www.saproxylic.org/>. Accessed 31st of July 2011.

Alexander, K.N.A., 2002. The invertebrates of living and decaying timber in Britain and Ireland, A provisional annotated checklist. English Nature Research Report 467

Brixey, J., 2000. The use of entomopathogenic nematodes to control the immature stages of the large pine weevil, Hylobius abietis. PhD Thesis, University of Reading, UK.

Buck, M., Bathon, H., 1993. Effects of a field application of entomopathogenic nematodes (Heterorhabditis sp.) on the non-target fauna, Part 2: Diptera. Anzeiger Fur Schadlingskunde Pflanzenschutz Umweltschultz 66, 84-88.

Csontos, A.S., 2002. Lateral movement of the entomopathogenic nematodes Steinernema glaseri and Heterorhabditis bacteriophora in Ssand at different temperatures in response to host seeking. Biocontrol Science and Technology $12,137-139$.

Delfosse, E.S., 2005. Risk and ethics in biological control. Biological control 35, 319329

Dillon, A., Ward, D., Downes, M.J., Griffin, C.T., 2006. Suppression of the large pine weevil, Hylobius abietis (Coleoptera: Curculionidae) by entomopathogenic nematodes with different foraging strategies. Biological Control 38, 217-226.

Dillon, A., Downes, M.J., Ward, D., Griffin, C.T., 2007. Optimizing application of entomopathogenic nematodes to manage large pine weevil, Hylobius abietis I (Coleoptera: Curculionidae) populations developing in pine stumps Pinus sylvestris. Biological Control 40, 253-263.

Dillon, A.B., Meade, C., Rolston, A., Downes, M.J., Griffin, C.T., 2008a. Establishment, persistence and introgression of entomopathogenic nematodes in a forest ecosystem. Ecological Applications 18, 735-747.

Dillon, A.B., Moore, C.P., Downes, M.J., Griffin, C.T., 2008b. Evict or infect? Managing populations of the large pine weevil, Hylobius abietis, using a bottom-up and top-down approach. Forest Ecology and Management 255, 2634-2642.

Dufrene, M., Legendre, P., 1997. Species assemblages and indicator species: the need for a flexible asymmetrical approach. Ecological Monographs 67, 345-366.

Ennis, D.E., Dillon, A.B., Griffin, C.T., 2010. Pine weevils modulate defensive behaviour in response to parasites of differing virulence. Animal Behaviour $80,283-288$.

Forsythe, T.G., 2000. Ground Beetles: Naturalists' Handbooks Vol 8. Richmond Publishing, Richmond, UK.

Forst, S., Dowds, B., Boemare, N., Stackebrandt, E., 1997. Xenorhabdus and Photorhabdus spp.: bugs that kill bugs. Annual Review of Microbiology 51, 47-72.

Georgis, R., Kaya, H.K., Gaugler, R., 1991. Effect of Steinernematid Herterorhabditid nematodes (Rhabditida: Steinernematidae and Heterorhabditidae) on nontarget arthropods. Environmental Entomology 20, 815-822.

Georgis, R., Koppenhofer, A.M., Lacey, L.A., Belair, G., Duncan, L.W., Grewal, P.S., Samish, M., Tan, L., Torr, P., van Tol, R.W.H.M., 2006. Successes and failures in the use of parasitic nematodes for pest control. Biological Control 38, 103-123.

Gouge, D.H., 2002. Applications for social insect control. In: Grewal, P.S., Ehlers, R.U. Shapiro-Ilan, D.I. (Eds.), Nematodes as Biocontrol Agents. CABI Publishing, Wallingford, UK, pp. 317-329.

Harvey, C.D., Alameen, K.M., Griffin, C.T., 2012. The impact of entomopathogenic nematodes on a non-target, service-providing longhorn beetle is limited by targeted application when controlling forestry pest Hylobius abietis. Biological Control 62, 173-182.

Jabbour, R., Barbercheck, M.E., 2011. Soil microarthropod response to the application of entomopathogenic nematode-killed insects in maize and sunflower strip habitats. Pedobiologia 54, 243-251.

Jonsell, M., Hansson, J., Wedmo, L., 2007. Diversity of saproxylic beetle species in logging residues in Sweden - comparisons between tree species and diameters. Biological Conservation 138, 89-99.

Jost, L., 2007. Partitioning diversity into independent alpha and beta components. Ecology 88, 2427-2439.

Joy, N.H., 1932. A Practical Handbook of British Beetles. Witherby, London, UK.

Kenkel, N.C., Orlóci, L., 1986. Applying metric and nonmetric multidimensional scaling to ecological studies: Some new results. Ecology 67, 919-928.

Koch, U., Bathon, H., 1993. Results of the outdoor application of entomopathogenic nematodes on non-objective fauna, part I: Coleoptera. Anzeiger Fur Schadlingskunde Pflanzenschutz Umweltschultz 66, 65-68.

Koppenhofer, A.M., Fuzy, E.M., 2009. Long-term effects and persistence of Steinernema scarabaei applied for suppression of Anomala orientalis (Coleoptera: Scarabaeidae). Biological Control 48, 63-72.

Leather, S.R., Day, K.R., Sailsbury, A.N., 1999. The biology and ecology of the large pine weevil, Hylobius abietis (Coleoptera: Curculionidae): a problem of dispersal? Bulletin of Entomological Research 89, 3-16.

Lindhe, A., Lindelöw, A., 2004. Cut high stumps of spruce, birch, aspen and oak as breeding substrates for saproxylic beetles. Forest Ecology and Management 203. $1-20$.

Lindroth, C.H., 1974. Handbook for the identification of British insects (Coleoptera: Carabidae), vol. IV. Royal Entomological Society of London, London, U.K.

Lola-Luz, T., Downes, M., 2007. Biological control of black vine weevil Otiorhynchus sulcatus in Ireland using Heterorhabditis megidis. Biological control 40, 314-319.

Loya, L.J., Hower, A.A., 2003. Infectivity and reproductive potential of the Oswego strain of Heterorhabditis bacteriophora associated with life stages of the clover root curculio, Sitona hispidulus. Journal of Invertebrate Pathology 83, 63-72. 
Luff, M., 2007. RES Handbook Volume 4 Part 2: The Carabidae (Ground Beetles) of Britain and Ireland. Field Studies Council, Shropshire, UK.

Lynch, L.D., Thomas, M.B., 2000. Non target effects in the biocontrol of insects with insects, nematodes and microbial agents: the evidence. Biocontrol News and Information 21, 117-130.

McCune, B., Grace, J.B., 2002. Analysis of Ecological Communities. MjM Software Design. Gleneden Beach, Oregon.

Millar, L.C., Barbercheck, M.E., 2001. Interaction between endemic and introduced entomopathogenic nematodes in conventional-till and no-till corn. Biological Control 22, 235-245.

MINITAB Inc, 2007. MINITAB Statistical Software, Release 15 for Windows. State College, PA, USA.

Norlander, G., Nordenhem, H., Bylund, H., 1997. Oviposition patterns of the pine weevil Hylobius abietis. Entomologica Experimentalis et Applicata 85, 1-9.

Parkman, J.P., Frank, J.H., Walker, T.J., Schuster, D.J., 1996. Classical biological control of Scapteriscus spp (Orthoptera: Gryllotalpidae) in Florida. Environmental Entomology 25, 1415-1420.

Peck, D.C., 2009. Comparative impacts of white grub (Coleoptera: Scarabaeidiae) control products on the abundance of non-target soil-active arthropods in turfgrass. Pedobiologia 52, 287-299.

Peters, A., 1996. The natural host range of Steinernema and Heterorhabditis spp. and their impact on insect populations. Biocontrol Science and Technology 6, 389402.

Poinar Jr., G.O., 1979. Nematodes for Biological Control of insects. CRC Press, Boca Raton, Florida.

Puza, V., Mracek, Z., 2010. Mechanisms of coexistence of two sympatric entomopathogenic nematodes, Steinernema affine and S. kraussei (Nematoda: Steinernematidae), in a central European oak woodland soil. Applied Soil Ecology 45, 65-70.
Rojht, H., Kac, M., Trdan, S., 2009. Nontarget effect of entomopathogenic nematodes on larvae of twospotted lady beetle (Coleoptera: Coccinellidae) and green lacewing (Neuroptera: Chrysopidae) under laboratory conditions. Journal of Economic Entomology 102, 1440-1443.

Shapiro-Ilan, D.I. Cottrell, TE, 2005. Susceptibility of lady beetles (Coleoptera: Coccinellidae) to entomopathogenic nematodes. Journal of Invertebrate Pathology 89, 150-156.

Tomalak, M., 2004. Infectivity of entomopathogenic nematodes to soil-dwelling developmental stages of the tree leaf beetles Altica quercetorum and Agelastica alni. Entomologia Experimentalis et Applicata 110, 125-133.

Trdan, S., Vidrih, M., Valic, N., Laznik, Z., 2008. Impact of entomopathogenic nematodes on adults of Phyllotreta spp. (Coleoptera: Chrysomelidae) under laboratory conditions. Acta Agriculturae Scandinavica 58, 169-175.

Tyler, G., 2008. Differences in abudance, species richness, and body size of ground beetles (Coleoptera: Carabidae) between beech (Fagus sylvatica L.) forests on Podzol and Cambisol. Forest Ecology and Management 256, 2154-2159.

Van Lenteren, J.C., Babendreier, D., Bigler, F., Burgio, G., Hokkanen, H.M.T., Kuske, S., Loomans, A.J.M., Menzler-Hokkanen, I., van Rijn, P.C.J., Thomas, M.B. Tommasini, M.G., Zeng, O.O., 2003. Environmental risk assessment of exotic natural enemies using in inundative biological control. Biocontrol 48, 3-38.

Wallace, H.R., 1953. The ecology of the insect fauna of pine stumps. Journal of Animal Ecology 22, 154-171.

Wang, Y., Crocker, R.L., Wilson, L.T., Smart, G., Wei, X., Nailon, W.T., Cobb, P.P., 2001. Effect of nematode and fungal treatments on non-target turfgrass-inhabiting arthropod and nematode populations. Environmental Entomology 30, 196-200.

Woodring J.L. Kaya, HK, 1988. Steinernematid and heterorhabditid nematodes: A handbook of techniques. Southern Cooperative Series Bulletin 331, Arkansas Agricultural Experimental Station, Fayetteville, USA 